\title{
A NEW SPECIES AND GENUS OF BRACHIOPODA FROM THE WESTERN APPROACHES, AND THE GROWTH STAGES OF THE LOPHOPHORE
}

\author{
By D. Atkins, D.Sc. \\ From the Plymouth Laboratory \\ (Plate I and Text-figs. I-I4)
}

A new species and genus of brachiopod has been dredged by R.V. 'Sarsia' on three cruises to the Western Approaches of the English Channel and two to the $\mathrm{La}$ Chapelle Bank region. In general appearance it closely resembles Dallina septigera (Lovén) with which it appears to have been confused by Fischer \& Oehlert (I89r).

In 1956 it was obtained on 13 June at position $48^{\circ} 33^{\prime}$ N., $10^{\circ} 05^{\prime} \mathrm{W}$. at a depth of $570-770$ fathoms, four specimens of shell length $17-25 \mathrm{~mm}$ were taken together with seven $D$. septigera.

On 3 May 1957 at position $48^{\circ} 33^{\prime}$ N., $10^{\circ}$ or' W., depth $580-680$ fathoms, a specimen of shell length $22 \mathrm{~mm}$ and an entire shell, I9 mm long, were taken accompanied by one $D$. septigera. The bottom in both positions was complex, mostly stone, shell and coral gravel, with some mud and boulders. The brachiopods were attached to worn fragments of coral, shell or stone.

During a cruise in the winter of 1958 the new species and $D$. septigera were dredged in some numbers and on this occasion there was little mixing of the two species. On 28 November at position $48^{\circ} 24^{\prime}-26^{\prime} \mathrm{N}$., $10^{\circ} 12^{\prime}-08^{\prime} \mathrm{W}$., depth 540-650 fathoms, twelve specimens (shell length $3.6-24 \mathrm{~mm}$ ) of the new species were taken: no Dallina occurred in this haul. On the 29 November at position $48^{\circ} 32^{\prime}-33^{\prime} \mathrm{N}$., $10^{\circ} 10^{\prime}-09^{\prime} \mathrm{W}$., depth $375-490$ fathoms, amongst twenty-seven $D$. septigera was a single specimen (shell length $15 \mathrm{~mm}$ ) of the new species and also six Macandrevia cranium (Müller). On 30 November at position $48^{\circ} 38^{\prime} \mathrm{N}$., $9^{\circ} 47^{\prime}-48^{\prime} \mathrm{W}$., depth 5 IO-550 fathoms, eighteen individuals (shell length $2 \cdot 7-22 \mathrm{~mm}$ ) of the new species were dredged together with a single Dallina septigera. On the same date in position $48^{\circ} 39^{\prime}-38^{\prime} \mathrm{N}$., $9^{\circ} 45^{\prime}-50^{\prime}$ W., 580-510 fathoms, one perfect specimen (shell length $19 \mathrm{~mm}$ ), parts of a further three and one entire shell of the new species were obtained, together with one $D$. septigera, and the posterior ends of another two. On this I958 cruise the new species was taken mainly attached to the dead region of growing coral, Lophelia prolifera (L.) Probably because the coral afforded shelter, a number of small specimens were found, the smallest being of shell length $2 \cdot 7 \mathrm{~mm}$ and width $2 \cdot 3 \mathrm{~mm}$. 
In the La Chapelle Bank region ( $47^{\circ} \mathrm{II}^{\prime}-\mathrm{I}^{\prime}$ N., $6^{\circ} \mathrm{I} 3^{\prime}-\mathrm{II}^{\prime}$ W., 625 fathoms) on 2 July 1959 one specimen (smashed) of shell length 7-8 $\mathrm{mm}$ was dredged, together with two Dallina.

From a second cruise in the La Chapelle Bank region $\left(47^{\circ} 37^{\prime} \mathrm{N} ., 7^{\circ} 27^{\prime} \mathrm{W}\right.$., 395 fathoms) on II July I959, five of the new species (shell length I 5-25 mm) were obtained in the same dredge haul as sixty-two Dallina. These brachiopods were from a chalky bottom and were attached to minute pieces of calcareous rock, and a few to living Limopsis (about $8 \mathrm{~mm}$ high) and Limopsis valves. In both species the pedicles were short. The specimens of the new species were of a broad and deep type; the four large ones had the following proportions: (I) $25 \mathrm{~mm}$ long, $24 \mathrm{~mm}$ wide, I9 mm deep (Pl. I, fig. 4); (2) and (3) $24 \mathrm{~mm}$ long, $22 \mathrm{~mm}$ wide, $17 \mathrm{~mm}$ deep; (4) $24 \mathrm{~mm}$ long, $22 \mathrm{~mm}$ wide, I6. $5 \mathrm{~mm}$ deep. The new species is almost as variable in general shape as is Dallina septigera.

Altogether some forty-six specimens of the new species, shell length 2.7-25 $\mathrm{mm}$, have been dredged.

All figures have been drawn with the aid of a camera lucida.

Fallax gen.nov.

Dallinid brachiopod with hinge teeth supported at all sizes by dental plates: deep, sessile pedicle collar. Loop passing through the growth stages characteristic of dallinids to reach the adult form, which is campagiform: ascending branches very broad, joined with the descending as far posterior as the junction with the septum, the two forming a gutter. Adult lophophore plectolophous. Spicules abundant, but not coarse, occurring in the lophophore, including the outer filaments, the body wall and over the mantle sinuses.

\section{Fallax dalliniformis sp.nov.}

The shell is variable in shape, elongate ovate to subpentagonal-rarely almost as wide as long - and broadest anteriorly (Pl. I). The two largest specimens were $25 \mathrm{~mm}$ long, $22.5 \mathrm{~mm}$ wide, $16.5 \mathrm{~mm}$ deep (Pl. I, fig. 5 and Text-fig. 5) and $25 \mathrm{~mm}$ long, $24 \mathrm{~mm}$ wide, I9 mm deep (Pl. I, fig. 4). The hinge line is curved; the shell is broadly sulcate to intraplicate; the test fairly thin and smooth; growth lines little marked; punctations somewhat finer and denser than in Dallina septigera; colour in the young creamy white, in adults fulvous or brownish owing to some deposit, possibly of manganese oxide. The beak is erect, the beak-ridges rounded. The deltidial plates are disjunct in the young (Text-fig. I A); fusion occurs at a shell length of some Io $\mathrm{mm}$ and the pedicle opening is then entire; the line of fusion is generally apparent even in adults (Text-fig. IC). The otherwise circular foramen runs down in a small ' $v$ ' in front, the base of the ' $v$ ' being produced inwards as a small projection on each side(Text-fig. I C), into which runs a beak ridge; in individuals with short pedicles the projections are sometimes absent owing to abrasion. Dental plates support the strong hinge teeth at all sizes, vertical in the young (Text-fig. I B) they become curved in adults. (Dental plates are absent in D. septigera brought in by R.V. 'Sarsia', at least down to a shell length of II.5 mm.) From the anterior corner of each dental plate a narrow ridge runs 
forward for a short distance. The deep sessile pedicle collar has a striated appearance owing to the longitudinal direction of the pits (Text-fig. IB).

Cardinalia characterized by a platform which in adults tends to jut ledge-like over the rather thick septum (Text-fig. $2 \mathrm{~B}, \mathrm{C}$ ). Even in the young the anterior edge of the platform is approximately at right angles to the septum, making a T-shape with it (Text-fig. $2 \mathrm{~A}$ ). (In D. septigera the cardinalia are less heavy, the hinge plates are generally markedly excavate, and in both young and adults the inner hinge plates curve gently to the thin-edged septum, giving a V-shaped outline.)

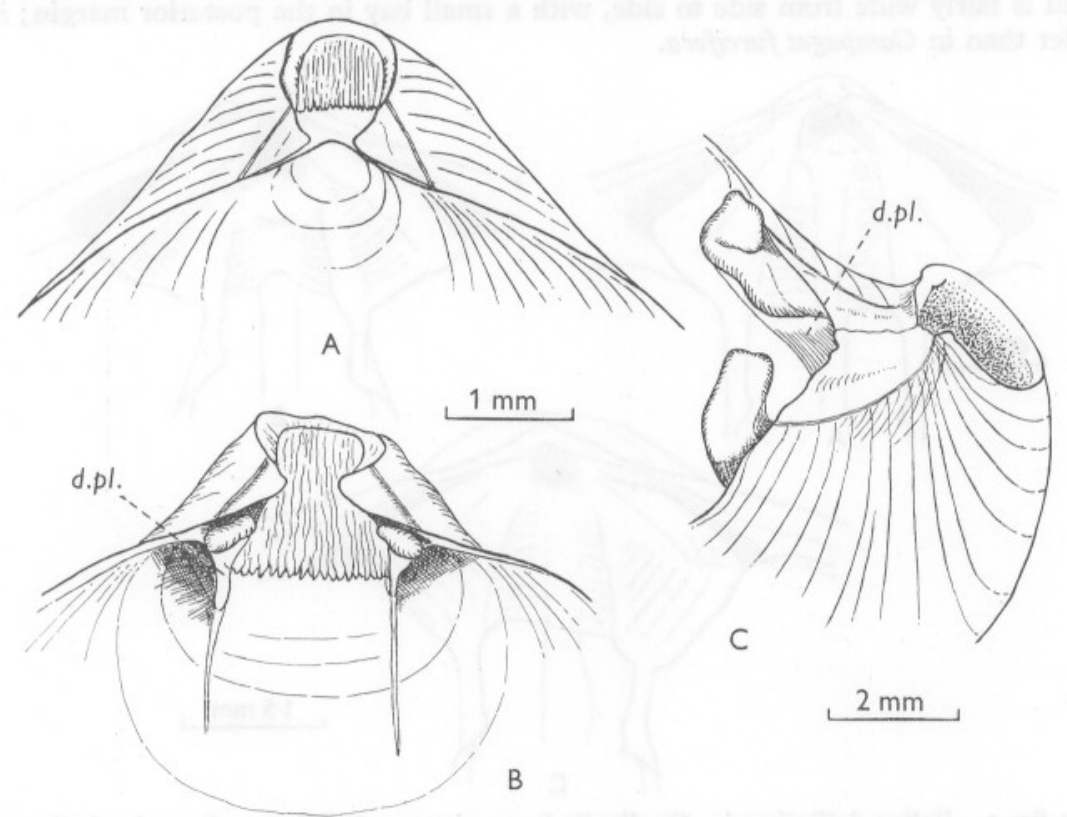

Text-fig. I. Fallax dalliniformis. A, umbonal region of specimen of shell length $7 \cdot 3 \mathrm{~mm}$ and width $6.8 \mathrm{~mm}$. Deltidial plates are disjunct at this stage. B, beak of same specimen tilted somewhat on to its tip so as to reveal the dental plates, with ridges running forward from their anterior corners, and the sessile pedicle collar of striated appearance. C, beak of adult specimen of shell length $24 \mathrm{~mm}$ and width $20 \mathrm{~mm}$. Oblique side view to show the shape of the unworn foramen and the conjunct deltidial plates. $d . p l$., dental plate.

In young Fallax dalliniformis the crura arise from the inner socket ridges (Textfig. 8): in adults their position shifts nearer the mid-line. No obvious crural bases, separating outer and inner hinge plates, as in Dallina septigera, can be distinguished, possibly because of the heavier cardinalia.

A cardinal process is absent; the diductor muscles are inserted on the floor of a small depression in front of the dorsal umbo (Text-fig. 2C), as in Macandrevia cranium (see Thomson, 1927, p. 240); in some individuals a small boss (Text-fig. 2 B), in others a triangular elevation (Text-fig. $2 \mathrm{~A}$ ) is present in front of the depression.

In the brachial valve the median septum, rather broad posteriorly, extends forward for about three-quarters of its length.

The loop does not reach as far forward as the septum (Text-fig. 3). The crura are short (Text-fig. 2) and the crural processes small. The adult loop is campagiform, rather than terebrataliform, resembling that of Campages furcifera Hedley (Hedley, 
1905). The descending branches are connected with the septum in all the large specimens obtained, and the very broad ascending branches are joined with the descending as far posteriorly as the junction with the septum, the two forming a gutter (Text-fig. 3). Some specimens, not always the largest, show a greater degree of resorption of the ascending branches than do others (Text-fig. 3 C, D), but even so, the ascending form a gutter with the descending as far backwards as the junction of the latter with the septum. The loop illustrated is very similar to that of a specimen of 'Dallina septigera', $25 \mathrm{~mm}$ long figured by Fischer \& Oehlert (I891, pl. v, fig. 9, $a c$ ). The transverse band is fairly wide from side to side, with a small bay in the posterior margin; it is wider than in Campages furcifera.

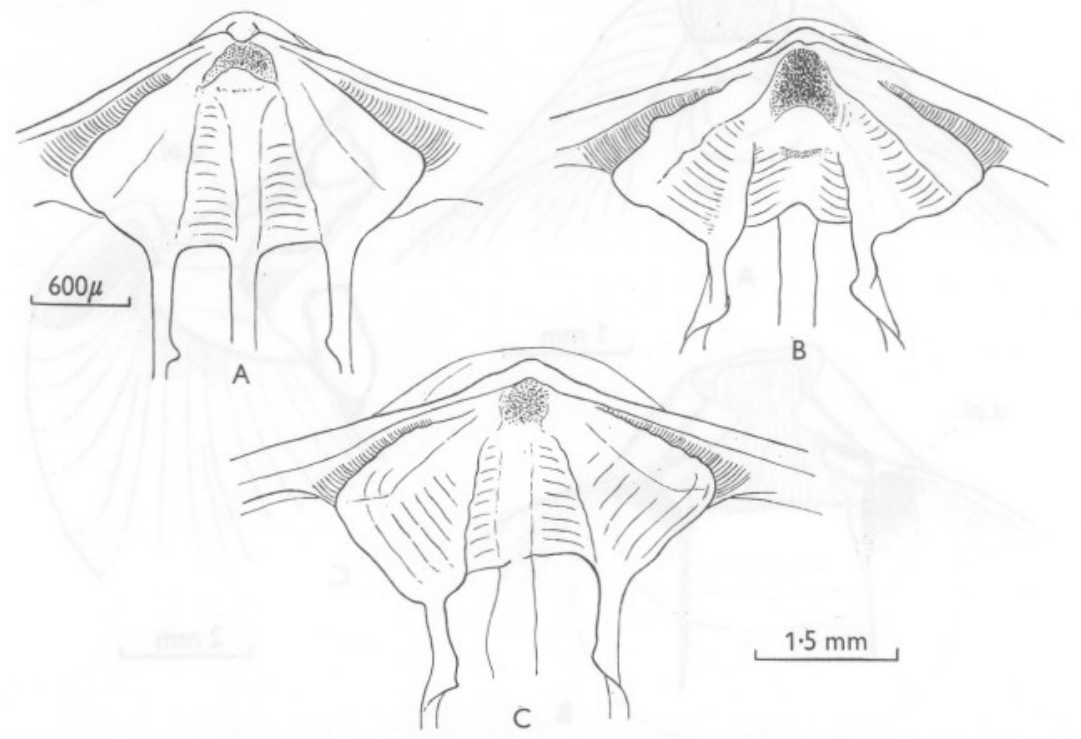

Text-fig. 2. Fallax dalliniformis. Cardinalia in specimens of different sizes: A, shell length $\mathrm{II} \cdot 5 \mathrm{~mm}$ and width $\mathrm{II} \cdot 0 \mathrm{~mm}$; B, shell length $\mathrm{I}_{7} \mathrm{~mm}$ and width $\mathrm{I} 4 \mathrm{~mm}$; $C$, shell length $2 \mathrm{Imm}$ and width $17 \mathrm{~mm}$.

The slender pedicle, very short in the young, reached a length of II $\mathrm{mm}$ in adults attached to large pieces of coral, but was short in those attached to rock and small objects.

The ventral pedicle muscle impressions are strongly marked and bounded laterally by ridges running from the anterior corners of the dental plates (Text-fig. $4 \mathrm{~A}, \mathrm{~B}$ ). A median elongated depression bounded laterally by raised ridges, marks the position of attachment of the diductor and adductor muscles; the impressions of the two are not clearly separated. The position of the ventral pedicle muscles relative to that of the adductor and diductor muscles changes with age, as does the relative size (Text-fig. $4 \mathrm{~A}, \mathrm{~B})$; at a shell length and width of $15 \mathrm{~mm}$ the surface of attachment of the ventral pedicle muscles is large (Text-fig. $4 \mathrm{~B}$ ). In the brachial valve the anterior and posterior adductor muscles are inserted separately on each side of the septum, the attachment of the two being almost in line with one another. The dorsal pedicle muscles are inserted on the hinge plate.

Two pairs of mantle sinuses are present in each valve.* In the brachial valve

$\star$ The mantle sinuses were demonstrated by soaking the valves in an aqueous solution of Aniline blue for a few days. 
(Text-fig. 4 C) the inner pair run alongside the median septum to its anterior end and then diverge, each sinus branching near the mantle margin. The outer pair after their origin from the coelomic cavity run almost parallel with the valve edge giving off short exterior branches. This distribution is similar to that in Dallina septigera (see Fischer \&

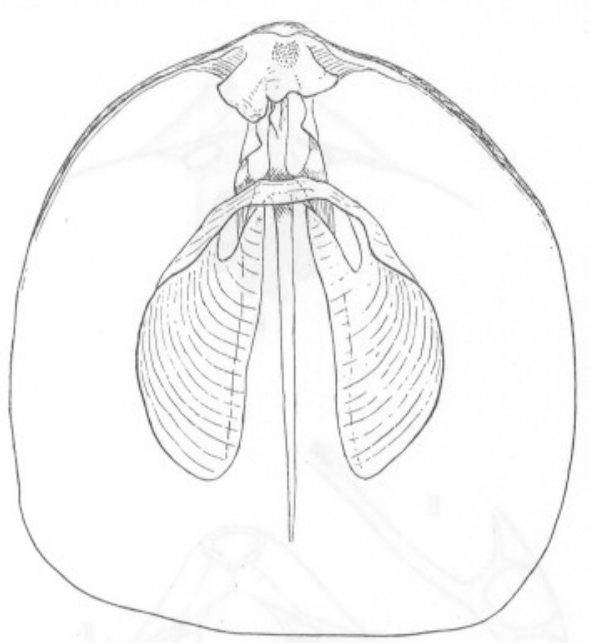

A
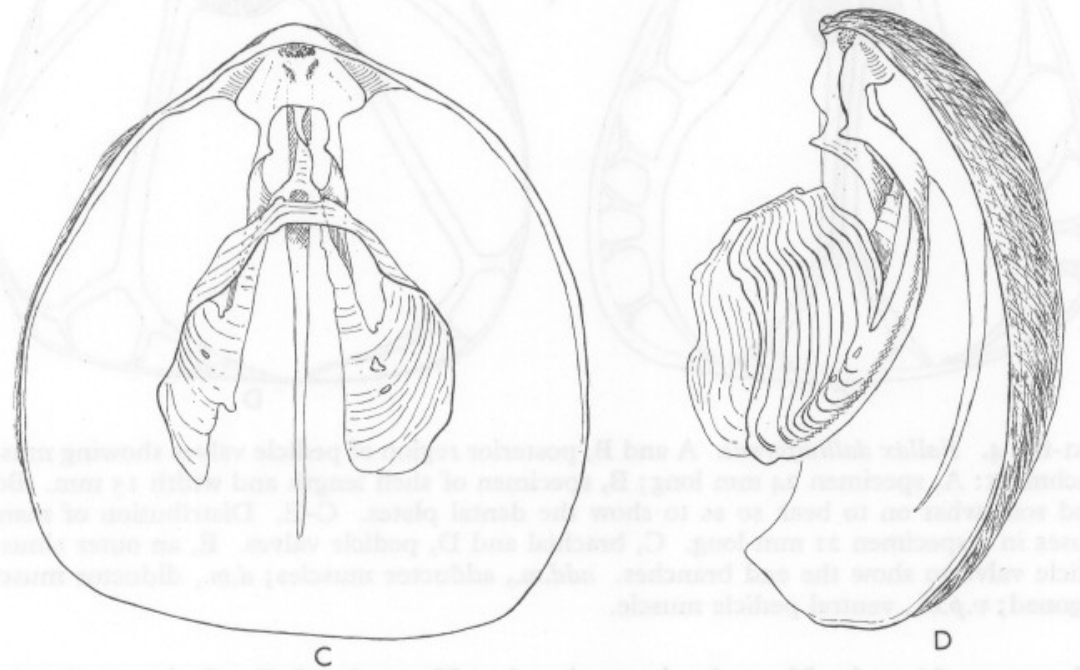

Text-fig. 3. Fallax dalliniformis. Interior of brachial valve of two specimens. A and B, of shell length $24 \mathrm{~mm}$ and width $20 \mathrm{~mm}$; the left inner socket ridge is abnormally large. C and $\mathrm{D}$, of shell length $2 \mathrm{I} \mathrm{mm}$ and width $17 \mathrm{~mm}$. The ascending branches show uneven development. The right descending branch had an abnormal growth anterior to the crural process, near an injury and mend to the valve: these abnormalities have been omitted. 
Oehlert, I89I) except that the lateral sinuses appear to diverge more widely and in the only Fallax examined the first branch arose at some considerable distance from the coelomic cavity. In the pedicle valve (Text-fig. $4 \mathrm{D}, \mathrm{E}$ ) the inner pair diverge widely, and the inner branch of each is long, the two almost meeting on the mid-anterior margin. In Dallina septigera these sinuses are nearly parallel (Fischer \& Oehlert, I89I,
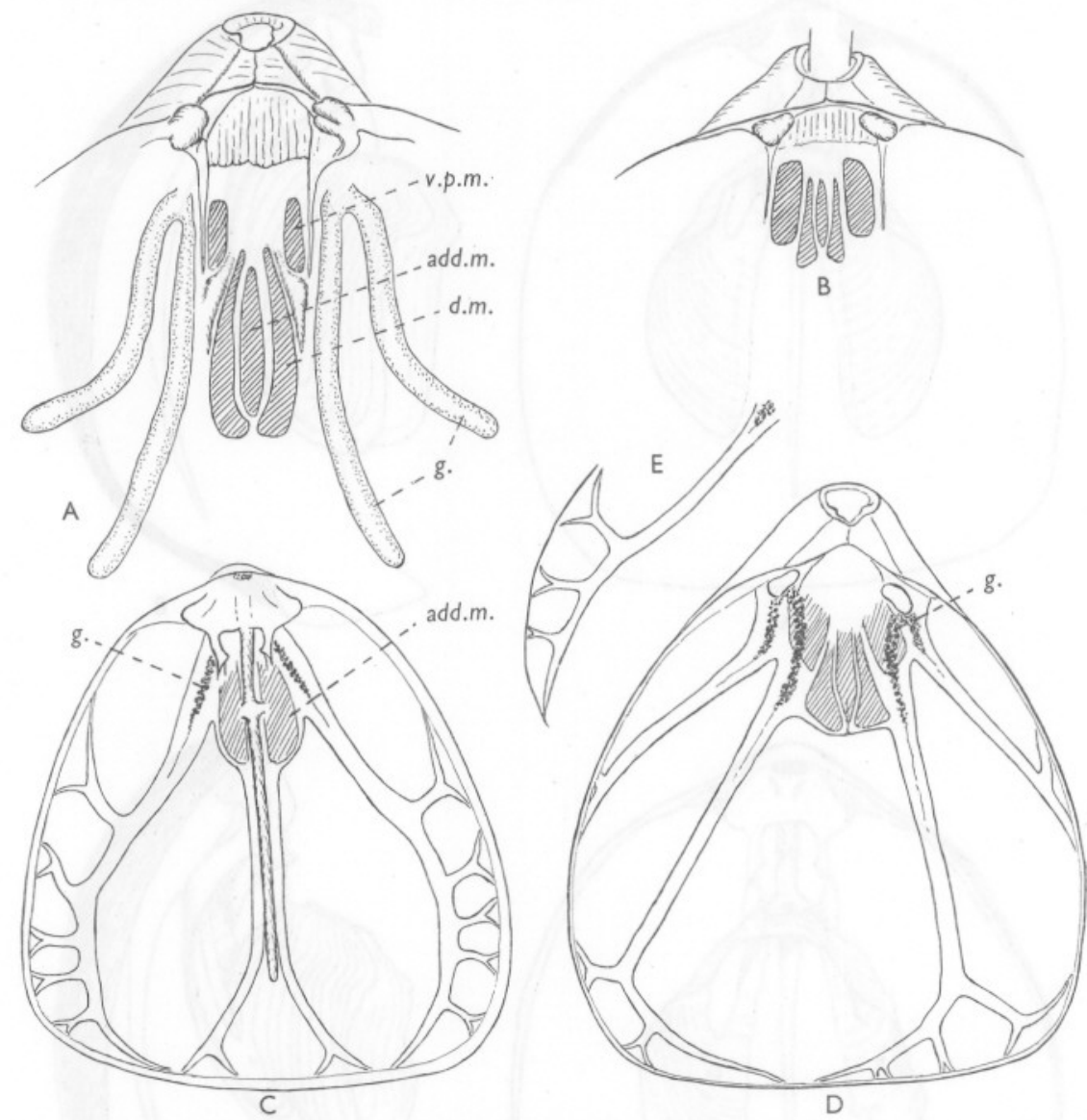

Text-fig. 4. Fallax dalliniformis. A and B, posterior region of pedicle valves showing muscle attachment: A, specimen $24 \mathrm{~mm}$ long; B, specimen of shell length and width $15 \mathrm{~mm}$. Both tilted somewhat on to beak so as to show the dental plates. C-E. Distribution of mantle sinuses in a specimen $2 \mathrm{I} \mathrm{mm}$ long. C, brachial and D, pedicle valves. E, an outer sinus of pedicle valve to show the end branches. add.m., adductor muscles; d.m., diductor muscle; g., gonad; v.p.m., ventral pedicle muscle.

and own work), as in Macandrevia cranium (see Hancock, I858). Owing to the deep concavity of the ventral valve the outer branches of the lateral sinuses are not visible in ventral view, only when the valve is tilted on to its side (Text-fig. $4 \mathrm{E}$ ).

The distribution of the gonad is as in M. cranium (see Hancock, I858) and Dallina septigera (see Fischer \& Oehlert, 189I). The sexes appear to be separate, but sectioning 
has not been carried out, and it is possible that alternation in the production of sex cells may occur.

The mantle setae are short and closely set in the adult.

The adult lophophore is plectolophous, with an alternating series of inner and outer filaments, except behind the mouth where some thirty-six are in single series. Spicules are present in the lophophore, including the outer, grooved filaments to about half of

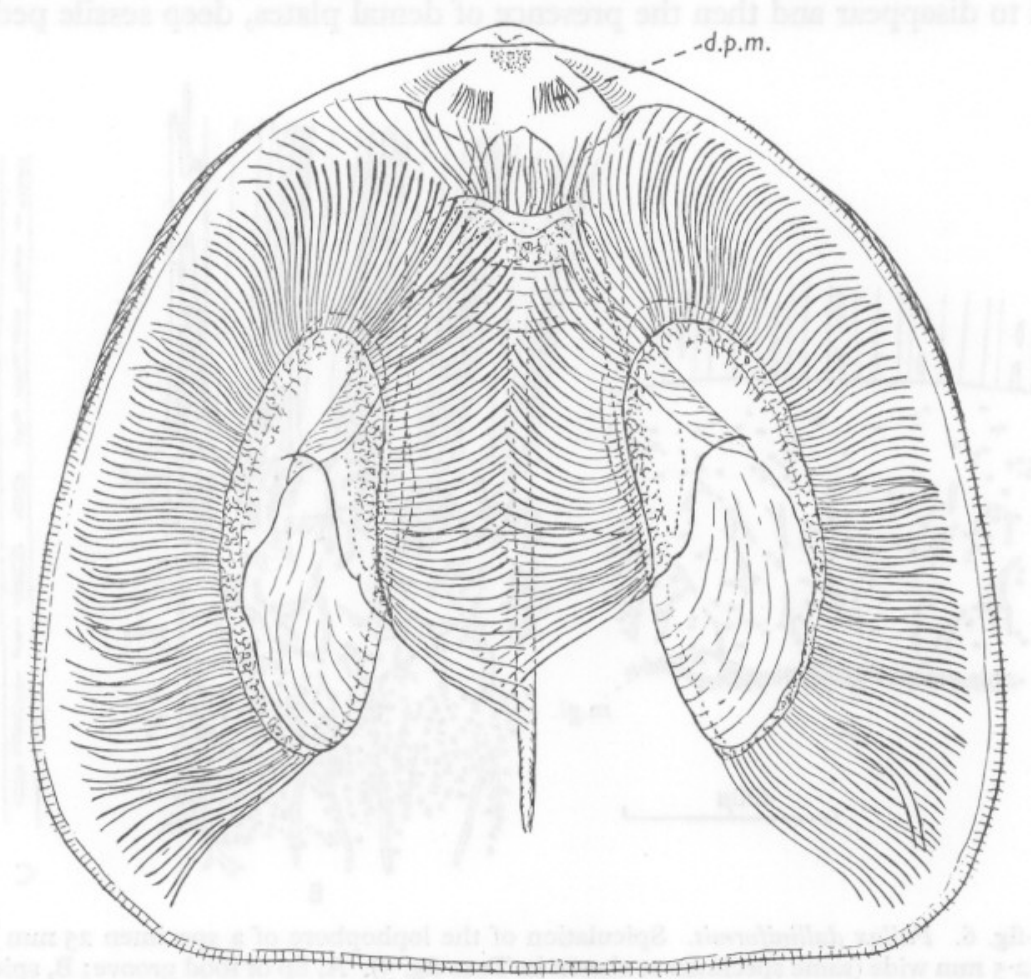

Text-fig. 5. Fallax dalliniformis of shell length $25 \mathrm{~mm}$ and width $22.5 \mathrm{~mm}$. Brachial valve with plectolophe drawn living: alimentary canal omitted. Loop added after clearing in cedar wood oil. d.p.m., dorsal pedicle muscle.

their length, in the body wall and over the mantle sinuses (Text-figs. 6, 7), in this differing strikingly from $D$. septigera. The spicules are fairly fine, of irregular spidery branching, especially those in the body wall and over the mantle sinuses (Text-fig. 7). The deep band of mucous cells at the base of the filaments when full of spherules hides the spicules in that position (see Text-fig. I4).

Fallax dalliniformis lacks the two carmine pigment spots found in connexion with the preoesophageal ganglion in certain brachiopods, as does also Dallina septigera and Macandrevia cranium.

The ciliary feeding mechanism is as described for M. cranium by Atkins, (1956). In large living specimens the valves may gape anteriorly as much as $6 \mathrm{~mm}$. 
With practice Fallax dalliniformis can be distinguished externally from Dallina septigera by the difference in the shape of the pedicle opening. The presence of abundant spiculation is the character by which living Fallax dalliniformis is most quickly distinguished from Dallina septigera, but in specimens long preserved in alcohol or in formalin, unless neutralized, these tend to disappear and then the presence of dental plates, deep sessile pedicle

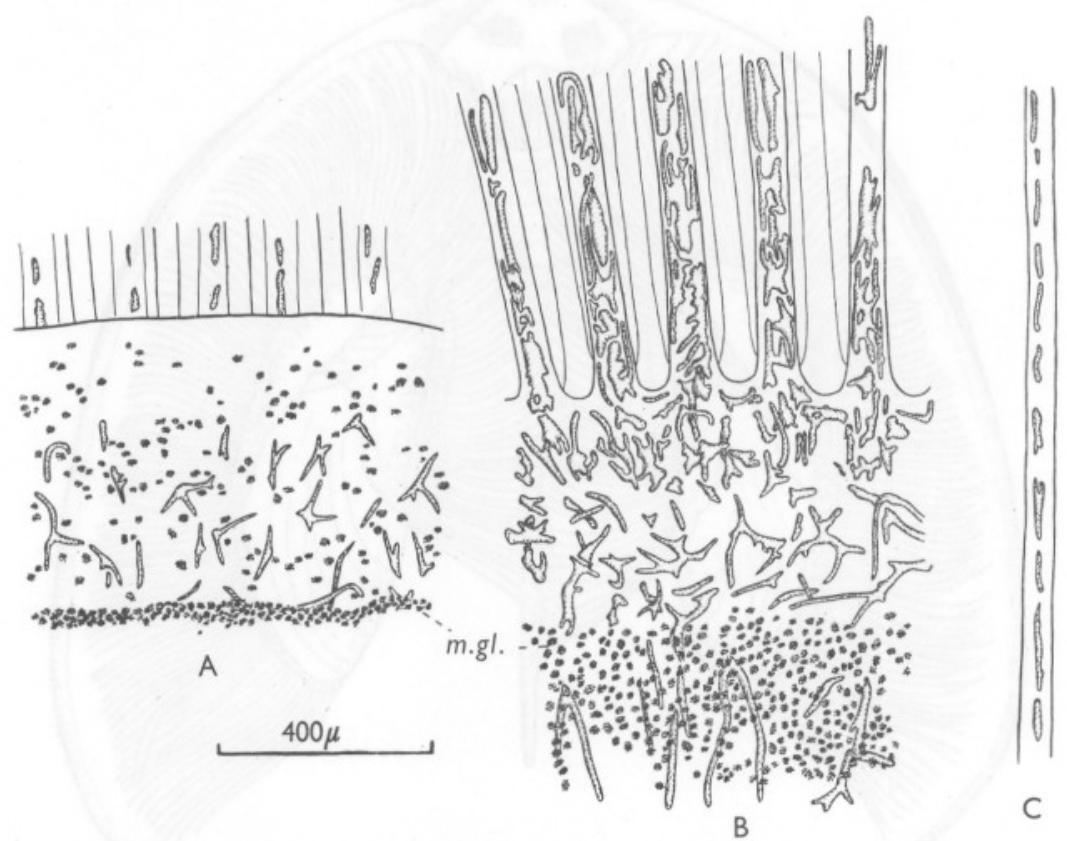

Text-fig. 6. Fallax dalliniformis. Spiculation of the lophophore of a specimen $25 \mathrm{~mm}$ long and $22.5 \mathrm{~mm}$ wide (same specimen as shown in Text-fig. 5). A, lip of food groove; B, spicules in outer grooved filaments and between their bases and the loop, seen from the abfrontal surface, C, outer grooved filament at extreme distal region of spiculation. m.gl., mucous gland cells.

collar and the differences in cardinalia and loop clearly separate the new species from $D$. septigera. Although D. septigera can be described as lacking spicules, in one individual a few minute, widely scattered spicules were found in the lophophore after a careful search. Dall (I87I, p. I6) has recorded the presence of a very few exceedingly delicate spicules in the floor of the greater mantle sinuses in D. floridana.

\section{Type locality}

Western Approaches to the English Channel in an area $48^{\circ} 24^{\prime}-39^{\prime} \mathrm{N}$., $9^{\circ} 45^{\prime}-10^{\circ} 12^{\prime} \mathrm{W}$., at a depth of $375^{-770}$ fathoms. 


\section{Type specimens}

As the first specimens obtained in 1956 have been damaged in the post, the single Fallax dalliniformis of 3 May $1957,48^{\circ} 33^{\prime}$ N., $10^{\circ}$ or $^{\prime}$ W., $580-680$ fathoms has been chosen as the holotype (P1. I, fig. I). Two specimens of 28 November 1958, $48^{\circ} 24^{\prime}-26^{\prime}$ N., $10^{\circ} 12^{\prime}-08^{\prime}$ W., 540-650 fathoms (P1. I, figs. 2,3 ) and one of II July I959, $47^{\circ} 37^{\prime}$ N., $7^{\circ} 27^{\prime}$ W., 395 fathoms (P1. I, fig. 4) have been chosen as paratypes. These specimens will be deposited in the British Museum (Natural History) when they can be conveyed there safely.
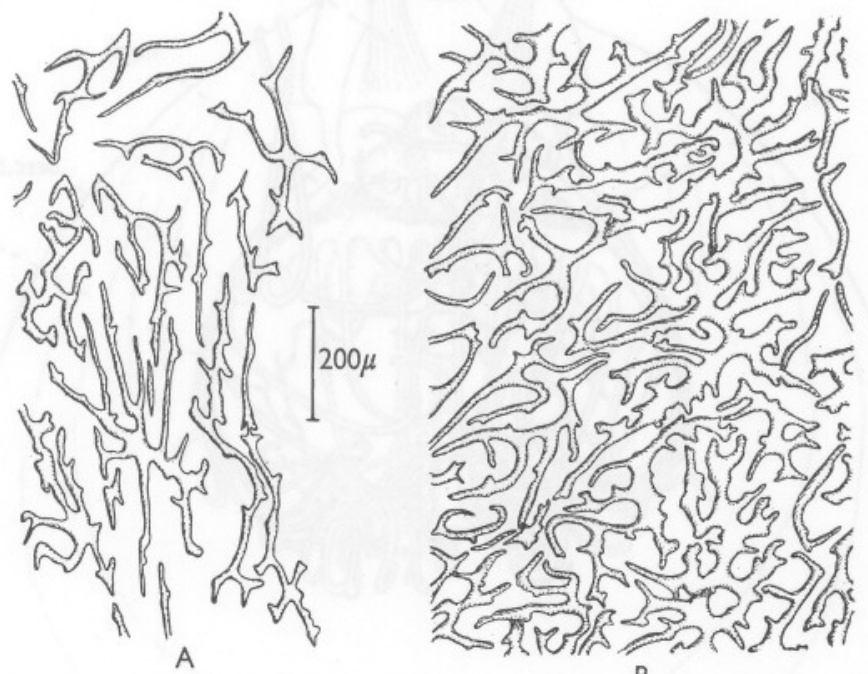

B

Text-fig.7. Fallaxdalliniformis. Spiculation of (A) body wall of individual $22 \mathrm{~mm}$ long and I6 mm wide; of (B) mantle over the male gonad of specimen $21 \mathrm{~mm}$ long and $15.5 \mathrm{~mm}$ wide.

\section{Breeding}

The breeding season is not known; it may possibly be in the winter months. In June 1956, of the four specimens obtained, the sex of the smallest, of shell length $17 \mathrm{~mm}$, could not be determined. Two of shell length 24 and $25 \mathrm{~mm}$ were males with tailed sperm in the gonad, and the fourth, of shell length $21 \mathrm{~mm}$, was a female. In both sexes the gonad was small. In November 1958 seven males (shell length $16-24 \mathrm{~mm}$ ) had tailed sperm in their gonads. Two specimens (shell length I9 and $24 \mathrm{~mm}$ ) had gonads of fair size; in the other five they were small. In five females of shell length $18-22 \mathrm{~mm}$ although the ova were large and round, the gonads were mostly small. In six of shell length 9-20 $\mathrm{mm}$ no gonad was discernible, and in a further two of shell length 20 and $22 \mathrm{~mm}$ sex could not be determined without sectioning. The four large $F$. dalliniformis of July 1959 had the gonads visible through the shells which were not opened. 


\section{GROWTH STAGES OF THE LOPHOPHORE AND LOOP}

Some few immature individuals have been found allowing of certain of the growth stages to be described. The smallest, of shell length $2.7 \mathrm{~mm}$ and width $2.3 \mathrm{~mm}$ already showed spicules at the bases of the filaments, on the brachial membrane of the schizolophous lophophore and in the body wall. In this individual it appeared as though the widely curved descending branches were

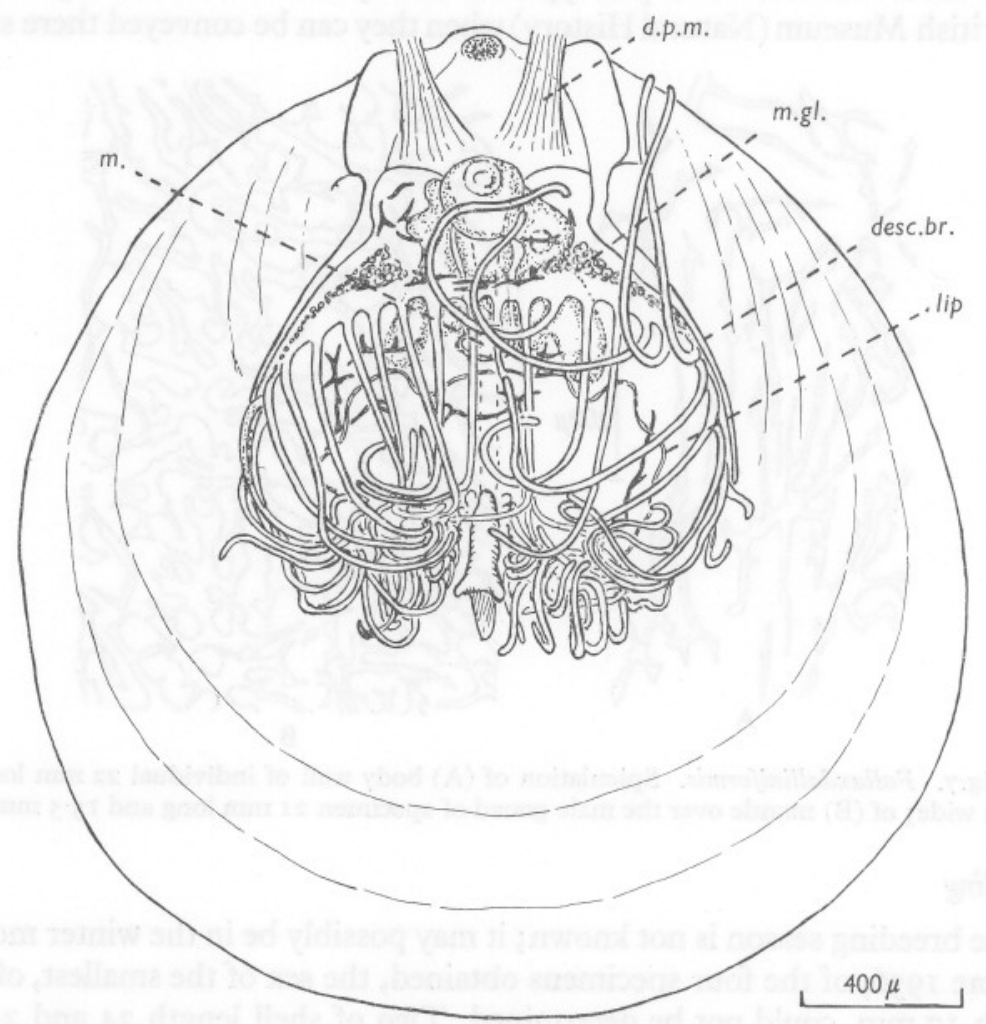

Text-fig. 8. Fallax dalliniformis of shell length $2.9 \mathrm{~mm}$ and width $2.4 \mathrm{~mm}$. Brachial valve with schizolophe; the descending branches (desc.br.) are incomplete. Preserved specimen. d.p.m., dorsal pedicle muscle; lip, edge of lip of food groove; $m$., mouth; m.gl., mucous gland cells. Spicules are indicated.

continued by long spicules; it was, however, impossible to be certain that these were not fractured ends of the branches. If they were, then the descending branches extended about half way around the lophophore. (It is not intended to imply that the loop is formed by fusion of spicules, but possibly they support the lophophore until the descending branches are fully formed.) The septum posteriorly bore a small hood of somewhat irregular shape. 
In a slightly larger specimen of shell length $2.9 \mathrm{~mm}$ and width $2.4 \mathrm{~mm}$ the descending branches were easier to distinguish and extended rather more than half way around the lophophore, which was of the broad-based terebratellacean type, set low on the dorsal mantle (Text-fig. 8). When complete, the descending branches of the loop, following the outline of the lophophore, would be almost circular, as in Macandrevia cranium (Atkins, 1959b); it is only in later stages that they make an acute angle with the septum. Unlike the smaller specimen, the median septum had as yet no recognizable hood; anteriorly it bore two short blunt projections. In both these small individuals the septum was connected with the cardinalia by a low ridge.

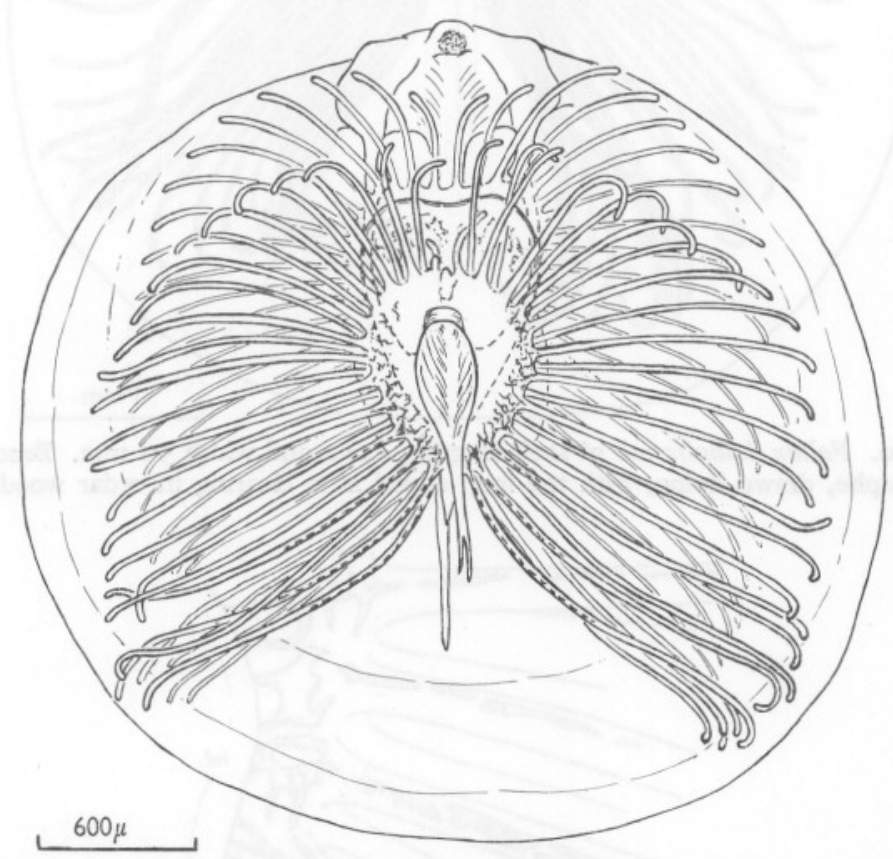

Text-fig. 9. Fallax dalliniformis of shell length $3.6 \mathrm{~mm}$ and width $3.3 \mathrm{~mm}$. Brachial valve with late schizolophe, drawn living, with the loop added after clearing in cedar wood oil. The descending branches are complete: the hood is open posteriorly. The gut is omitted.

From these two specimens it is evident that the descending branches arise early in development, although not as early as in $M$. cranium, and that the septum is more forward in development than in the latter species, in which a hood does not appear until after the completion of the descending branches (Atkins, 1959b). That the descending branches grow from the crura only can unfortunately not be proved, as the necessary stage is wanting. It is, however, probable, for although the descending branches were long, no lateral projections were present on the septum. 


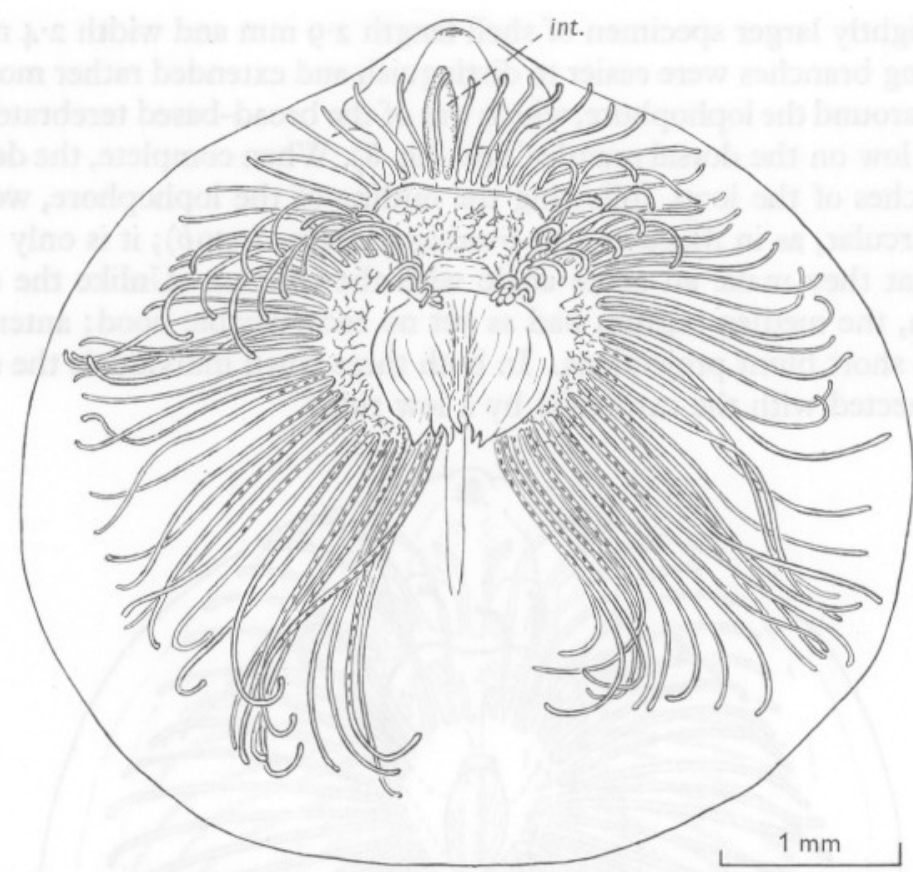

Text-fig. 10. Fallax dalliniformis of shell length $5.4 \mathrm{~mm}$ and width $5.1 \mathrm{~mm}$. Brachial valve with zygolophe, drawn living, with the loop added after clearing in cedar wood oil. int., intestine.

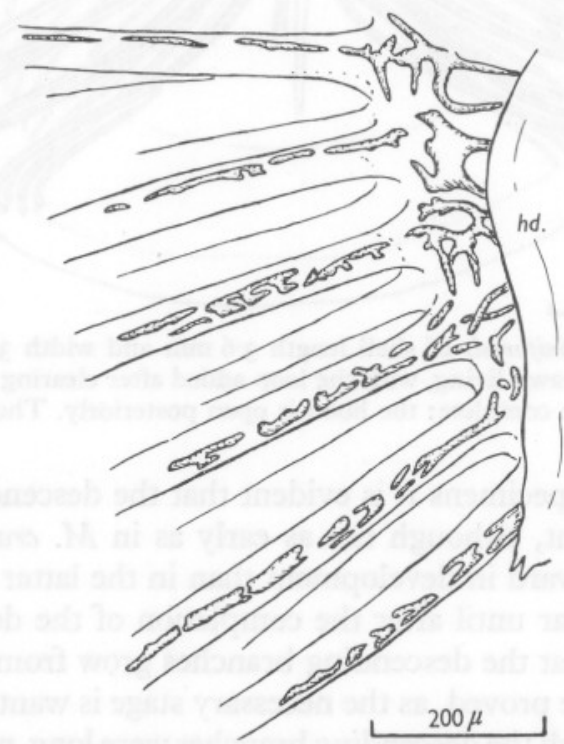

Text-fig. Ir. Fallax dalliniformis. Part of the lophophore shown in Text-fig ro, enlarged to show the spicules. hd., hood. 
At a shell length of $3.0 \mathrm{~mm}$ and width of $2.7 \mathrm{~mm}$ the lophophore was late schizolophous and the lateral arms were already deflected. The descending branches joined the septum at an acute angle: the hood was long, narrow and entire; the septum was produced into a long spine anteriorly. Spicules were now present in a few of the outer filaments situated at the anterior ends of the lateral arms.

Three specimens of nearly the same size and of about the same stage of development of the lophophore-late schizolophous to very early zygolophous -were obtained. In one of shell length $3.6 \mathrm{~mm}$ and width $3.2 \mathrm{~mm}$, the angular

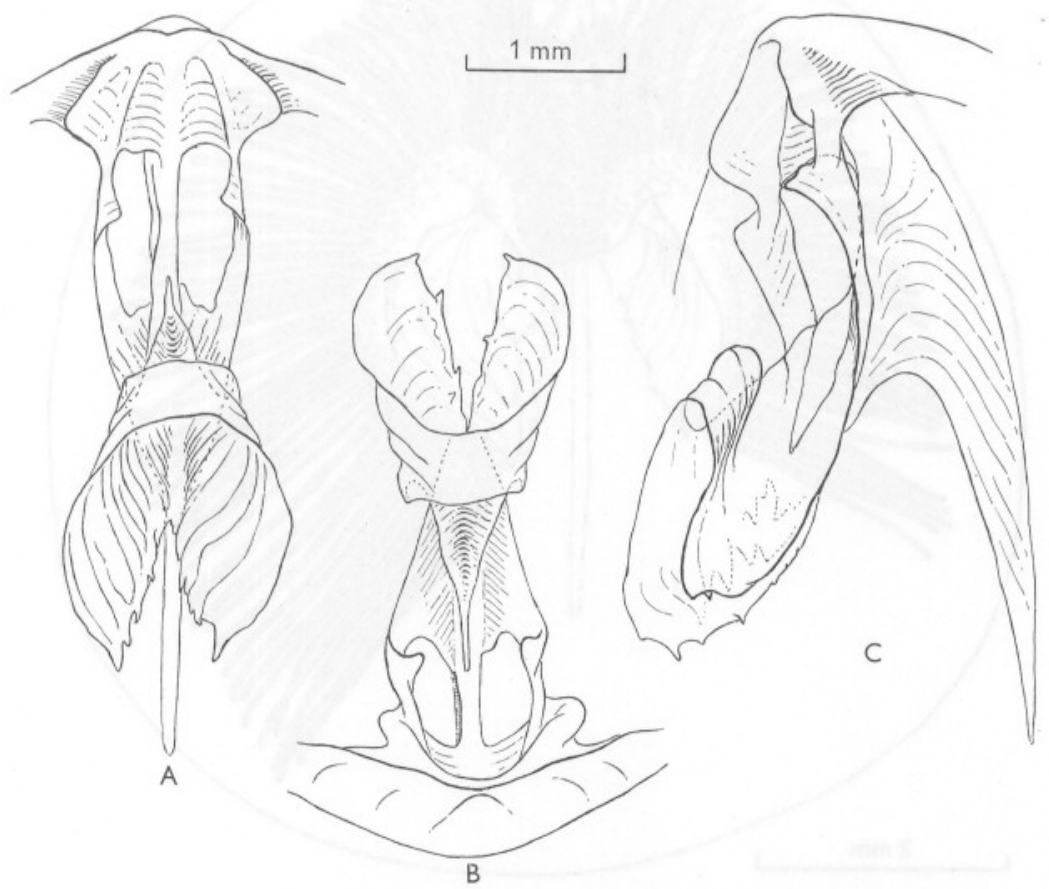

Text-fig. 12. Fallax dalliniformis. Loop of specimen $7 \cdot 3 \mathrm{~mm}$ long and $6.8 \mathrm{~mm}$ wide. $A$, ventral view; $B$, as seen when the valve is standing on its anterior edge; $C$, side view.

hood was the least developed of the three, the posterior end being entire. Anteriorly the septum had spinous projections. The hood of a slightly smaller individual of shell length $3.6 \mathrm{~mm}$ and width $2.7 \mathrm{~mm}$, was fairly broad and somewhat asymmetrical; the posterior end had undergone resorption. Anterior spinous projections were short and from their appearance it is possible that the hood had been damaged in life. The hood of the third individual of shell length $3.6 \mathrm{~mm}$ and width $3.3 \mathrm{~mm}$ was long, fairly narrow with high sides and was open posteriorly (Text-fig. 9). Anteriorly the septum was produced into long spines. It is evidently at about the size of these three 
specimens, when the lophophore is late schizolophous, that resorption of the posterior end of the hood occurs.

At a shell length of $4.8 \mathrm{~mm}$ and width of $4.4 \mathrm{~mm}$ the lophophore was early zygolophous; the hood, somewhat asymmetrical in shape, had widened; the transverse band was distinct. Long anterior spines still remained.

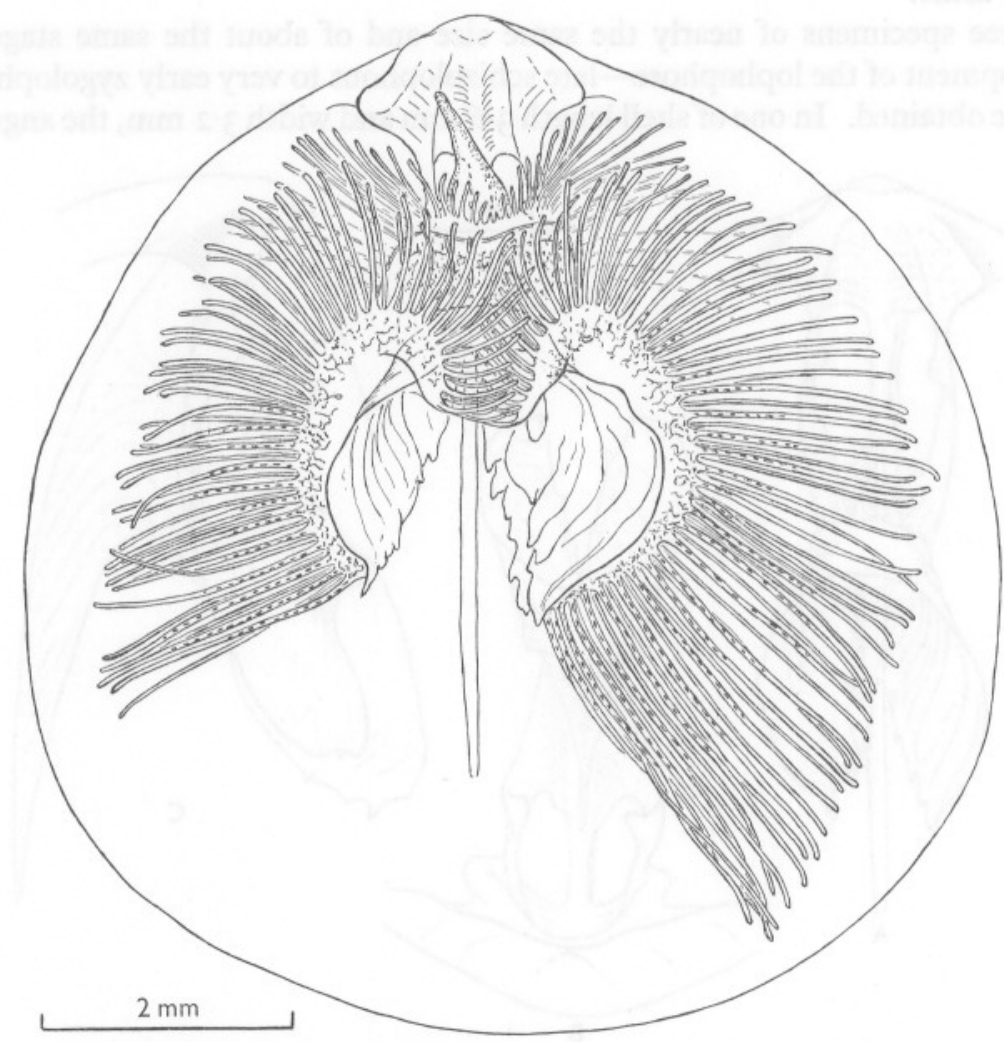

Text-fig. 13. Fallax dalliniformis of shell length $8.7 \mathrm{~mm}$ and width $7.8 \mathrm{~mm}$. Brachial valve with early plectolophe; the lateral arms most unevenly developed. Spicules are indicated.

The lophophore was zygolophous at a shell length of $5.4 \mathrm{~mm}$ and width of $5.1 \mathrm{~mm}$. The hood, or ascending branches of the loop, had widened greatly: slight anterior bifurcation was evident with short spines bordering it (Textfig. Io). Spicules in part of the lophophore are shown enlarged in Textfigure II. The loop extended to the middle of the valve.

A specimen of shell length $7.3 \mathrm{~mm}$ and width $6.8 \mathrm{~mm}$ was without flesh, so that three aspects of the loop could be drawn (Text-fig. I2). The hood was deeply divided anteriorly, the sides of the bifurcation being spinous. The sides of the hood, or broad ascending branches, were attached to the ventral surface 
of the septum as far backward as the posterior attachment of the descending branches, the two sides forming a ventrally facing gutter, extending beyond the transverse band of the loop. This is a slightly younger stage than that shown by Friele (1877, pl. iv, fig. 13) of Dallina septigera at a shell length of about $6.0 \mathrm{~mm}$ and is very similar.

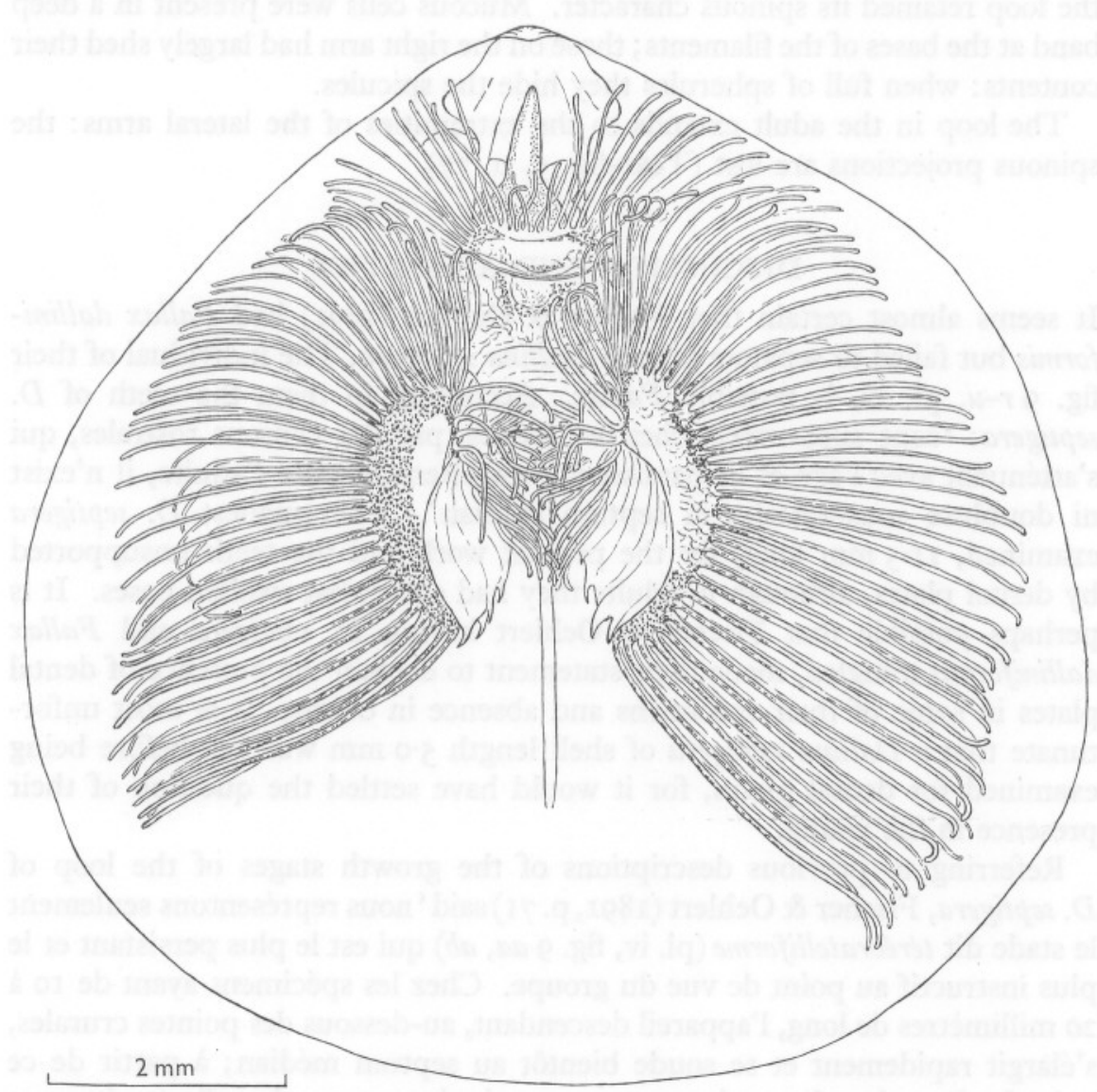

Text-fig. I4. Fallax dalliniformis of shell length $9.2 \mathrm{~mm}$ and width $8.9 \mathrm{~mm}$. Brachial valve with early, almost symmetrical, plectolophe. The position of the mucous cells on the lophophore is indicated where these are full of spherules, as on the left lateral arm and certain regions of the right arm. Spicules are only visible where the mucous cells have shed their contents.

At a shell length of $8.7 \mathrm{~mm}$ and width of $7.8 \mathrm{~mm}$ the lophophore was early plectolophous, with some three-quarters turn to the spiral arm (Text-fig. I3). In this specimen the lateral arms were most unequally developed. Spines were present along the inner, dorsal edges of the ascending branches. Resorption had begun posteriorly in the larger, right ascending branch. Spicules 
were present over the oesophagus, contrary to the condition in Platidia (Atkins, I959a).

In an individual of shell length $9.2 \mathrm{~mm}$ and width $8.9 \mathrm{~mm}$ with lateral arms almost symmetrically developed (Text-fig. I4), the early plectolophe had rather more than a complete turn to the median arm. The anterior region of the loop retained its spinous character. Mucous cells were present in a deep band at the bases of the filaments; those on the right arm had largely shed their contents: when full of spherules they hide the spicules.

The loop in the adult extends to the extremities of the lateral arms: the spinous projections are lost (Text-fig. 5, p. 77).

\section{DISCUSSION AND AFFINITIES}

It seems almost certain that Fischer \& Oehlert (I89I) had Fallax dalliniformis but failed to separate it from Dallina septigera. The individual of their fig. $9 r-u$, pl. iv, is possibly Fallax. According to them the teeth of $D$. septigera: 'sont supportées, chez les jeunes, par des cloisons rostrales, qui s'atténuent avec l'âge et disparaissent complètement chez l'adulte, il n'exist ni doublure sous-apicale, ni septum médian'. The smallest D. septigera examined, II.5 mm long, for the present work had the teeth unsupported by dental plates, although in adults they had somewhat swollen bases. It is perhaps possible that Fischer \& Oehlert having D. septigera and Fallax dalliniformis mingled, made their statement to explain the presence of dental plates in some of their specimens and absence in others. It is most unfortunate that a Dallina septigera of shell length $5.0 \mathrm{~mm}$ was lost before being examined for dental plates, for it would have settled the question of their presence in the young.

Referring to previous descriptions of the growth stages of the loop of D. septigera, Fischer \& Oehlert (I89I, p. 7I) said 'nous représentons seulement le stade dit térébratelliforme (pl. iv, fig. $9 a a, a b$ ) qui est le plus persistant et le plus instructif au point de vue du groupe. Chez les spécimens ayant de Io à 20 millimètres de long, l'appareil descendant, au-dessous des pointes crurales, s'élargit rapidement et se soude bientôt au septum médian; à partir de ce point les branches descendantes sont constituées par une lamelle étroitement repliée sur elle-même en forme de gouttière et dont la partie externe persiste seule dans les appareils arrivés à leur complet état de développement.' Thus according to them the gutter is formed entirely by the descending branch. It has been shown (p. 73-4) that this 'térébratelliforme' stage of Fischer \& Oehlert's ' $D$. septigera' is the adult loop of Fallax dalliniformis-indeed their fig. $9 a a$ and $a b$, pl. iv represent a somewhat idealized loop of $F$. dalliniformis with the cardinalia of that species-and the gutter is formed not by the descending branch alone, but by the fused descending and ascending branches, as in Campages furcifera Hedley. Thomson (1927, fig. $74 f$ ) reproduced 
their figure as a terebrataliform stage. In Dallina septigera dredged by R.V. 'Sarsia' the loop is entirely free from the septum from a shell length of about $13 \mathrm{~mm}$., and the ascending and descending branches are fused for a variable, but generally short, distance anteriorly (Atkins, 1960).

Fallax dalliniformis obtained in November 1958 from coral exhibited abnormalities of shell and internal structure, including asymmetry of shell valves (P1. I, fig. 2), loop (see Text-fig. 13) and cardinalia (Text-fig. 3A). Asymmetry of the shell resulting from injury was probably caused by the crowded branches and polyps of the coral; that of the loop and cardinalia may follow, or possibly be caused by predatory animals. As mentioned previously these Fallax from coral tended to have pedicles of up to II $\mathrm{mm}$ long.

It is impossible to place this new species in Dallina because of the presence at all sizes of dental plates, deep sessile pedicle collar, the difference in cardinalia and the presence of abundant spiculation; the presence of dental plates precludes it being placed in fapanithyris, a genus of which little is known; a new genus, Fallax, has therefore been created.

Fallax dalliniformis no doubt should be placed in the Dallinidae and most probably in the Dallininae, as now constituted because of its loop form, presence of dental plates, early development of the descending branches of the loop, probably growing from the crura only, and anterior bifurcation of the septum in the early stages, with spines on the loop. But while it is said (Thomson, I927, p. 23I) of the Dallininae that spicules are occasionally present, but never abundant, they are abundant, although not coarse, in $F$. dalliniformis, which in this differs from any genus of Dallininae so far described. It is possible that spiculation is present in other genera of the subfamily and has escaped notice, as apparently by Fischer \& Oehlert (I89I) in certain of their specimens of 'Dallina septigera'. Mr G. F. Elliott tells me that among specimens labelled D. septigera in the British Museum (Natural History) one dried specimen with T-shaped cardinalia shows glistening membranes suggesting strong spiculation.

In the presence of spicules Fallax dalliniformis approaches Laqueus, but the adult loops are entirely different, as is the folding. In addition to spicules it agrees with Laqueus in the presence of dental plates, sessile pedicle collar and absence of cardinal process, all characters in which it also agrees with certain of the Dallininae. Thomson (I927, p. 259) records of Laqueus 'small spicules present over the pallial sinuses, but not extending to the body-wall or lophophore'. In the few L. californianus (Küster) from Puget Sound, North America, that I examined, long delicate spidery spicules were present not only over the pallial sinuses, but also in the body wall, at the bases of the filaments behind the mouth, and between the two carmine pigment spots and the transverse band; I was unable to find them in the filaments or between their bases and the loop. Incidentally this species of Laqueus possesses two carmine pigment spots near the preoesophageal ganglion. 
Although the adult loop of Fallax dalliniformis resembles that of Campages, and especially that of $C$. furcifera Hedley, Fallax differs from Campages in possessing dental plates at all ages, lacking a cardinal process and possessing abundant spiculation.

My thanks are due to the Captain and crew of R.V. 'Sarsia' who dredged the brachiopods, and especially to Dr A. J. Southward and Mr G. R. Foster who were in charge of the scientific work, and who took great care of these delicate brachiopods during the journeys back to the laboratory. Those from the second cruise to the La Chapelle Bank region were very kindly picked out and cared for by $\mathrm{Mr} \mathrm{H}$. Gill (Cambridge University). I am indebted to $\mathrm{Mr}$ A. C. G. Best for the photographs in the plate: faults in blacking out the background are my responsibility. Mr G. F. Elliott most kindly read the manuscript. The work was done while occupying a London University table.

\section{SUMMARY}

A new species and genus, Fallax dalliniformis, of dallinid brachiopod is described from the Western Approaches to the English Channel, in the area $48^{\circ} 24^{\prime}-39^{\prime}$ N., $9^{\circ} 45^{\prime}-10^{\circ} \mathbf{I 2}^{\prime}$ W., depth $375-770$ fathoms, and from the La Chapelle Bank region $47^{\circ} \mathrm{II}^{\prime}-37^{\prime}$ N., $6^{\circ} \mathrm{II}^{\prime}-7^{\circ} 27^{\prime}$ W., $395-625$ fathoms. It is homoeomorphic with Dallina septigera (Lovén), with which it occurred in some dredge hauls. It is characterized by the possession of dental plates to the hinge teeth, deep sessile pedicle collar, a campagiform loop in the adult, spiculation in the lophophore, the body wall and over the mantle sinuses: in all these characters and in the cardinalia it differs from D. septigera. Shell length $25 \mathrm{~mm}$.

Growth stages of the lophophore from schizolophous to plectolophous are described. The loop passes through the growth stages characteristic of dallinids as far as the campagiform stage, which in this species is the adult loop.

\section{EXPLANATION OF PLATE I}

Fallax dalliniformis sp. et gen.nov.

Fig. I A-D. Dorsal, ventral, lateral and frontal views of the holotype, $22 \mathrm{~mm}$ long, $19 \mathrm{~mm}$ wide and $15.5 \mathrm{~mm}$ deep. May $1957,48^{\circ} 33^{\prime}$ N., $10^{\circ}$ or' W.; $580-680$ fathoms.

Figs. 2-4. Paratypes to show variation in shape.

Fig. 2A-D. Specimen $21 \mathrm{~mm}$ long, $15.5 \mathrm{~mm}$ wide and $15 \mathrm{~mm}$ deep. November 1958 , $48^{\circ} 24^{\prime}-26^{\prime}$ N., $10^{\circ} 12^{\prime}-08^{\prime}$ W.; 540-650 fathoms, on coral. Foraminifera attached to pedicle. Fig. 3A-D. Specimen $24 \mathrm{~mm}$ long, $20 \mathrm{~mm}$ wide and $17 \mathrm{~mm}$ deep. Obtained on same date and from same position as previous specimen.

Fig. 4A-D. Specimen $25 \mathrm{~mm}$ long, $24 \mathrm{~mm}$ wide and $19 \mathrm{~mm}$ deep. July 1959 , from chalk bottom, $47^{\circ} 37^{\prime}$ N., $7^{\circ} 27^{\prime} \mathrm{W}$.; 395 fathoms.

Fig. 5A, B. Ventral and frontal views of specimen $25 \mathrm{~mm}$ long, $22.5 \mathrm{~mm}$ wide and $16.5 \mathrm{~mm}$ deep. (The same specimen of which the brachial valve with plectolophe is shown in Textfig. 5 ; the loop is now smashed.) June $1956,48^{\circ} 33^{\prime}$ N., $10^{\circ} 05^{\prime}$ W.; $570-770$ fathoms.

(All photographed while in water. Approximately natural size.) 


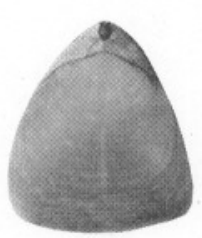

$1 \mathrm{~A}$

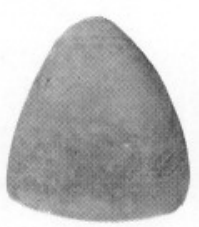

$1 \mathrm{~B}$

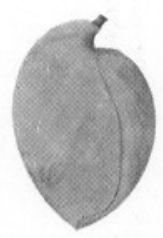

$1 \mathrm{C}$

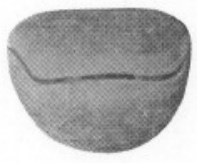

$1 \mathrm{D}$

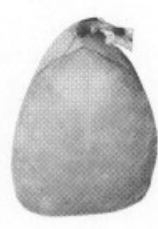

$2 \mathrm{~A}$

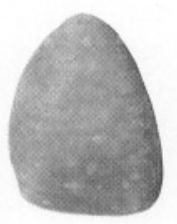

$2 B$

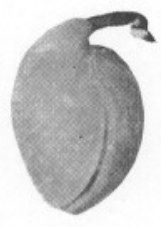

$2 \mathrm{C}$

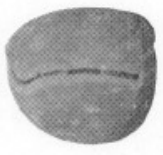

$2 \mathrm{D}$

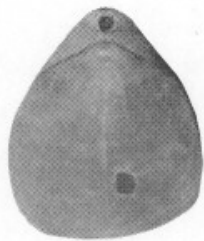

$3 \mathrm{~A}$

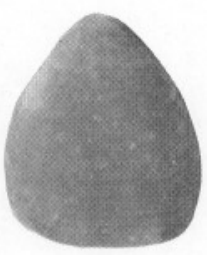

3 B

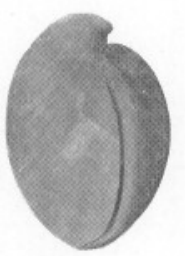

$3 \mathrm{C}$

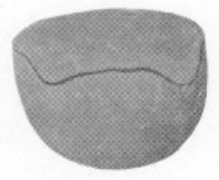

$3 \mathrm{D}$

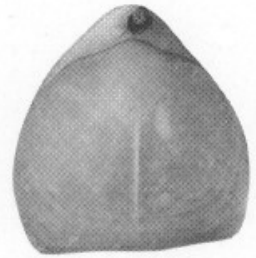

$4 \mathrm{~A}$

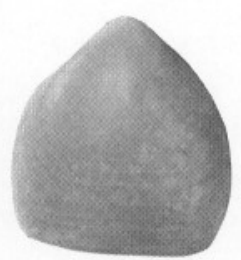

4B

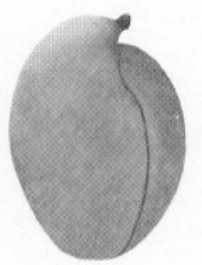

$4 C$

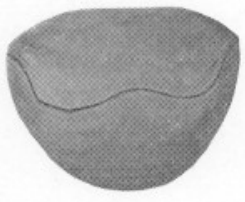

$4 \mathrm{D}$

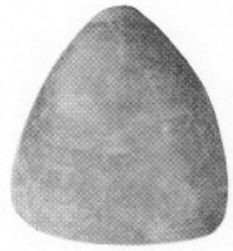

$5 \mathrm{~A}$

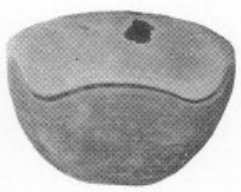

5 B

(Facing p. 88) 


\section{REFERENCES}

Atkins, D., 1956. Ciliary feeding mechanisms of brachiopods. Nature, Lond., Vol. 177, pp. 706-7.

- 1959a. The growth stages of the lophophore of the brachiopods Platidia davidsoni (Eudes Deslongchamps) and P. anomioides (Philippi), with notes on the feeding mechanism. F. mar. biol. Ass. U.K., Vol. 38, pp. I03-32.

- $1959 \mathrm{~b}$. The early growth stages and adult structure of the lophophore of Macandrevia cranium (Müller) (Brachiopoda, Dallinidae). F. mar. biol. Ass. U.K., Vol. 38, pp. 335-50.

— 1960. A note on Dallina septigera (Lovén) (Brachiopoda, Dallinidae). F. mar. biol. Ass. U.K., Vol. 39, pp. 9I-9.

DALL, W. H., I87I. Report on the Brachiopoda obtained by the United States coast survey expedition, in charge of L. F. de Pourtalès, with a revision of the Craniidae and Discinidae. Bull. Mus. comp. Zool. Harvard, Vol. 3, pp. I-45.

Fischer, P. \& OeHLERT, D.-P. I89I. Brachiopodes. Expéd. sci. Travailleur et Talisman, $140 \mathrm{pp}$.

FrIELE, H., I877. The development of the skeleton in the Genus Waldheimia. Arch. Math. Naturv., Bd. 2, pp. 380-6.

Hancock, A., I858. On the organization of the Brachiopoda. Phil. Trans. Vol. I48, pp. $79 \mathrm{I}-869$.

Hedley, C., 1905. Mollusca from one hundred and eleven fathoms, east of Cape Bryon, New South Wales. Rec. Aust. Mus., Vol. 6, pp. 4I-54.

Tномson, J. A., 1927. Brachiopod morphology and genera (Recent and Tertiary). N.Z. Bd. Sci. Art, Manual 7. 